\title{
Essential information on surgical heart valve characteristics for optimal valve prosthesis selection: Expert consensus document from the European Association for Cardio-Thoracic Surgery (EACTS)-The Society of Thoracic Surgeons (STS)-American Association for Thoracic Surgery (AATS) Valve Labelling Task Force
}

\author{
Andras P. Durko, MD, ${ }^{\mathrm{a}}$ Philippe Pibarot, DVM, PhD ${ }^{\mathrm{b}}$ Pavan Atluri, $\mathrm{MD},{ }^{\mathrm{c}}$ Vinayak Bapat, $\mathrm{MD},{ }^{\mathrm{d}}$ Duke E. \\ Cameron, MD, ${ }^{\mathrm{e}}$ Filip P. A. Casselman, MD, PhD,${ }_{\mathrm{f}}^{\mathrm{f}}$ Edward P. Chen, MD, ${ }^{\mathrm{g}}$ Gry Dahle, MD, ${ }^{\mathrm{h}}$ John A. Elefteriades, \\ MD, PhD, ${ }_{1}$ Patrizio Lancellotti, MD, PhD, ${ }^{j}$ Richard L. Prager, MD, ${ }^{\mathrm{k}}$ Raphael Rosenhek, MD,${ }^{1}$ Alan Speir, MD,${ }^{\mathrm{m}}$ \\ Marco Stijnen, $\mathrm{PhD},{ }^{\mathrm{n}}$ Giordano Tasca, $\mathrm{MD}, \mathrm{PhD},{ }^{\mathrm{o}}$ Ajit Yoganathan, $\mathrm{PhD},{ }^{\mathrm{p}}$ Thomas Walther, $\mathrm{MD}, \mathrm{PhD},{ }^{\mathrm{q}}$ and \\ Ruggero De Paulis, MD (Task Force Chairman), ${ }^{\mathrm{r}}$ EACTS-STS-AATS Valve Labelling Task Force*
}

\begin{abstract}
Comprehensive information on the characteristics of surgical heart valves (SHVs) is essential for optimal valve selection. Such information is also important in assessing SHV function after valve replacement. Despite the existing regulatory framework for SHV sizing and labelling, this information is challenging to obtain in a uniform manner for various SHVs. To ensure that clinicians are adequately informed, the European Association for Cardio-Thoracic Surgery (EACTS), The Society of Thoracic Surgeons (STS) and American Association for Thoracic Surgery (AATS) set up a Task Force comprised of cardiac surgeons, cardiologists, engineers, regulatory bodies, representatives of the International Organization for Standardization and major valve manufacturers. Previously, the EACTS-STS-AATS Valve Labelling Task Force identified the most important problems around SHV sizing and labelling. This Expert Consensus Document formulates recommendations for providing SHV physical dimensions, intended implant position and hemodynamic performance in a transparent, uniform manner. Furthermore, the Task Force advocates for the introduction and use of a standardized chart to assess the probability of prosthesis-patient mismatch and calls valve manufacturers to provide essential information required for SHV choice on standardized Valve Charts, uniformly for all SHV models. (J Thorac Cardiovasc Surg 2021;161:545-58)
\end{abstract}

\footnotetext{
From the ${ }^{\text {a Department }}$ of Cardiothoracic Surgery, Erasmus University Medical Cen-

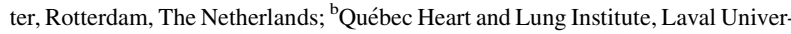

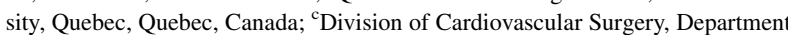
of Surgery, University of Pennsylvania, Philadelphia, Pa; ${ }^{\mathrm{d}}$ Department of Cardiovascular Surgery, New York-Presbyterian/Columbia University Medical Center, New York, NY; ' Division of Cardiac Surgery, Department of Surgery, Massachusetts General Hospital, Boston, Mass; ${ }^{\mathrm{f}}$ Department of Cardiovascular and Thoracic Surgery, OLV Clinic, Aalst, Belgium; ${ }^{\mathrm{g}}$ Division of Cardiothoracic Surgery, Department of Surgery, Emory University School of Medicine, Atlanta, Ga; ${ }^{\mathrm{h}}$ Department of Cardiothoracic and Thoracic Surgery, Rikshospitalet, Oslo University Hospital, Oslo, Norway; ${ }^{i}$ Department of Cardiothoracic Surgery, Yale University School of Medicine, New Haven, Conn; ${ }^{\mathrm{j}} \mathrm{GIGA}$ Cardiovascular Sciences, Department of Cardiology, University of Liège Hospital, Liège, Belgium; ${ }^{\mathrm{k}}$ Department of Cardiac Surgery, University of Michigan Hospital, Ann Arbor, Mich; ${ }^{1}$ Department of Cardiology, Medical University of Vienna, Vienna, Austria; ${ }^{\mathrm{m}}$ Department of Cardiac Surgery, Inova Heart and Vascular Institute, Falls Church, Va; ${ }^{n}$ LifeTec Group, Eindhoven, The Netherlands; ${ }^{\circ}$ Cardiac Surgery Unit, Heart Health Center, King Saud Medical City, Riyadh, Kingdom of Saudi Arabia; ${ }^{\mathrm{P}}$ Wallace H. Coulter Department of Biomedical Engineering, Georgia Institute of Technology/Emory School of Medicine, Atlanta, Ga; ${ }^{9}$ Department of Thoracic and Cardiovascular Surgery, University Hospital Frankfurt and Johann Wolfgang Goethe University, Frankfurt, Germany; and ${ }^{\mathrm{r} H e a r t}$ Surgery Division, European Hospital, Rome, Italy.

The Society of Thoracic Surgeons, the European Association for Cardio-Thoracic Surgery, and the American Association for Thoracic Surgery approved this document.
}

Document reviewers: Manuel Antunes (Portugal), Ko Bando (Japan), Wolfgang Bothe (Germany), Michael Bowdish (USA), Tomasz Timek (USA). The other reviewer wishes to remain anonymous.

This article has been copublished in The Journal of Thoracic and Cardiovascular Surgery, The Annals of Thoracic Surgery, and the European Journal of CardioThoracic Surgery.

The American Association for Thoracic Surgery requests that this article be cited as: Durko AP, Pibarot P, Atluri P, Bapat V, Cameron DE, Casselman FPA, et al. Essential information on surgical heart valve characteristics for optimal valve prosthesis selection: expert consensus document from the European Association for CardioThoracic Surgery (EACTS)-The Society of Thoracic Surgeons (STS)-American Association for Thoracic Surgery (AATS) Valve Labelling Task Force. J Thorac Cardiovasc Surg. 2021;161:545-58.

* A list of the EACTS-STS-AATS Valve Labelling Task Force members appears in the Appendix at the end of the article.

Address for reprints: Ruggero De Paulis, MD, Heart Surgery Division, European Hospital, Via Portuense 700, 00149 Rome, Italy (E-mail: rdepaulis58@gmail. com).

J Thorac Cardiovasc Surg 2021;161:545-58 $0022-5223 / \$ 36.00$

Copyright (C) 2020 Jointly between The Society of Thoracic Surgeons, the American Association for Thoracic Surgery, and the European Association for CardioThoracic Surgery Published by Elsevier Inc.

https://doi.org/10.1016/j.jtcvs.2020.10.001 
See Commentaries on pages 559 and 562.

Comprehensive and reliable information on the characteristics of surgical heart valves (SHVs) is essential for optimal valve selection. This information is also important in assessing SHV function after valve replacement. Despite the existing regulatory framework ${ }^{1,2}$ and the efforts by the International Organization for Standardization (ISO), ${ }^{3}$ the amount and quality of currently available information on SHV characteristics provided by manufacturers is not optimal and often not uniform, rendering intraoperative SHV selection challenging.

To ensure that clinicians are provided with the necessary information, the European Association for Cardio-Thoracic Surgery (EACTS), The Society of Thoracic Surgeons (STS) and American Association for Thoracic Surgery (AATS) established the EACTS-STS-AATS Valve Labelling Task Force, composed of cardiac surgeons, cardiologists, engineers, regulatory professionals and representatives of major valve manufacturing companies.

The first document of the Task Force addressed the following issues around SHV sizing and labelling: (1) non-uniform or incomplete reporting of SHV materials and physical dimensions; (2) non-uniform marking of SHV support structures (eg, sewing rings); (3) unclear definition of labeled valve size and inconsistencies between sizer dimensions and labeled valve size; (4) lack of robust information to reliably predict SHV hemodynamic performance; (5) lack of uniform tools to predict and prevent prosthesis-patient mismatch (PPM); and (6) lack of good-quality, robust clinical data on SHV thrombogenicity. ${ }^{4}$

This second Expert Consensus Document of the Task Force provides recommendations on the information that should be provided together with an SHV, to ensure consistent comparability of different SHVs and to facilitate optimal intraoperative SHV selection.

\section{PHYSICAL DIMENSIONS OF SURGICAL HEART VALVES}

Defining uniform, standardized physical dimensions is necessary to objectively compare various SHVs. Current ISO standards for cardiac valves provide definitions only for 'internal orifice diameter,' 'profile height' and 'outflow tract profile height, ${ }^{3}$ and manufacturers often use nonuniform terminology to describe the physical dimensions of their SHVs. Furthermore, it is not always easy to find detailed information on the physical dimensions of an SHV. ${ }^{5}$

The Task Force recommends that manufacturers provide the physical dimensions of SHVs using the terminology listed in Tables 1 and 2. Physical dimensions should be provided in millimetres, with preferably at least 1 decimal place precision. In addition, a pictogram of the SHV should be presented, clearly indicating the corresponding physical dimensions. Example tables and pictograms for standardized displaying of the physical dimensions of stented biological and mechanical SHVs in the aortic and mitral position are provided in Figures 1 and 2.

Although defined in the ISO 5840 standard, ${ }^{3}$ 'internal orifice diameter' (the minimum diameter within an SHV through which blood flows) is difficult to determine for certain bioprosthetic SHVs ${ }^{6}$ and some manufacturers have refrained from reporting it. In specific bioprosthetic SHV designs, the orifice available for flow is encircled by the prosthetic leaflets and it is smaller than the internal stent diameter (Figure 2, A). Furthermore, the uneven surface created by the leaflets makes exact measurements difficult. Considering the inconsistency in the use and reporting of 'internal orifice diameter,' the Task Force advocates the use of 'minimum internal diameter' to define the smallest diameter theoretically available for flow within an SHV orifice.

The minimum internal diameter of a bioprosthesis, also termed as 'true internal diameter (true ID),' is important when a valve-in-valve procedure is planned. ${ }^{6}$ Some have tried to determine this dimension of bioprosthetic SHVs by manually passing a circular sizing tool through the

TABLE 1. Physical dimensions of mechanical SHVs

\begin{tabular}{|c|c|c|c|}
\hline Physical dimension & Definition & $\begin{array}{r}\text { Label on } \\
\text { Figure } 1\end{array}$ & Reference \\
\hline Overall profile height & Maximal axial dimension of an SHV in the open or closed position, whichever is greater & A & 3 \\
\hline Outflow profile height & $\begin{array}{l}\text { Maximum distance that the SHV extends axially into the outflow tract in the open or closed } \\
\text { position, whichever is greater, measured from the valve structure intended to mate with } \\
\text { the top (atrial or aortic/pulmonic side) of the patient's annulus }\end{array}$ & B & 3 \\
\hline Minimum internal diameter* & The smallest diameter within an SHV orifice, which is theoretically available for flow & $\mathrm{C}$ & 3 \\
\hline External housing diameter & The largest external diameter of the supporting frame (housing) & $\mathrm{D}$ & $\dagger$ \\
\hline External sewing ring diameter & The largest diameter of the uncompressed sewing ring & E & $\dagger$ \\
\hline
\end{tabular}


TABLE 2. Physical dimensions of bioprosthetic SHVs

\begin{tabular}{|c|c|c|c|}
\hline Physical dimension & Definition & $\begin{array}{c}\text { Label on } \\
\text { Figure } 2\end{array}$ & Reference \\
\hline Overall profile height & Maximal axial dimension of an SHV in the open or closed position, whichever is greater & A & 3 \\
\hline Outflow profile height & $\begin{array}{l}\text { Maximum distance that the SHV extends axially into the outflow tract in the open or closed } \\
\text { position, whichever is greater, measured from the valve structure intended to mate with } \\
\text { the top (atrial or aortic/pulmonic side) of the patient's annulus }\end{array}$ & B & 3 \\
\hline Minimum internal diameter* & The smallest diameter within an SHV orifice, which is theoretically available for flow & $\mathrm{C}$ & 3 \\
\hline Internal stent diameter $\dagger$ & The smallest internal diameter of the supporting frame (stent), without fabric covering & $\mathrm{D}$ & $\ddagger$ \\
\hline External stent diameter $\dagger$ & The largest external diameter of the stent, with fabric covering & $\mathrm{E}$ & $\ddagger$ \\
\hline External sewing ring diameter ${ }^{\dagger}$ & The largest diameter of the uncompressed sewing ring & $\mathrm{F}$ & $\ddagger$ \\
\hline
\end{tabular}

SHV, Surgical heart valve; ISO, International Organization for Standardization. *Defined in the ISO 5840:2015 as 'internal orifice diameter.' †Not applicable for stentless bioprosthetic SHVs. ${ }^{\ddagger}$ Not defined in the ISO 5840:2015.

orifice of the SHV in $0.5 \mathrm{~mm}$ increments. ${ }^{6}$ However, these results might not be always accurate since the force used for passing the sizers through the orifice is not standardized. A standardized method for determining 'minimum internal diameter' during bench testing should be developed, and this dimension should be made available by the manufacturers, for all bioprosthetic SHV models and sizes, along with the other physical dimensions of the prosthesis. It is important that these determinations of this dimension are calculated in a similar standardized manner across all manufacturers with accepted protocols with reproducibility amongst laboratories.

\section{POSITION OF SURGICAL HEART VALVES RELATIVE TO THE ANNULUS}

The intended position of an SHV related to the patient tissue annulus has important implications on the surgical technique and more importantly on the hemodynamic performance of the SHV following implantation. ${ }^{7,8}$ Manufacturers should provide clear guidance regarding the intended implant position of an SHV. Currently, the terminology and definitions provided by the ISO 5840:2015 standard (Table 3) are used for this purpose. ${ }^{3}$ However, this terminology has certain shortcomings since it is unclear how certain aortic SHVs, primarily seated above but with partial extension into the annulus, should be classified. ${ }^{4}$

An easy way to overcome the ambiguity of the current 'supra-annular' and 'intra-annular' terminology is that manufacturers provide a standardized pictogram, clearly indicating the intended position(s) of the SHV after implantation, related to the tissue annulus of the patient. Example pictograms indicating the position of an aortic SHV related to the annulus are provided in Figure 3 for aortic and in Figure 4 for mitral mechanical and bioprosthetic valves.

\section{LABELED VALVE SIZE AND INTRAOPERATIVE SIZING}

The proper interpretation of 'labeled valve size' is one of the most challenging issues around SHV labelling, causing the most confusion in the surgical community. ${ }^{9}$ Labeled

Mechanical valves, aortic position

\begin{tabular}{|c|c|c|c|c|c|}
\hline \multirow{4}{*}{$\begin{array}{c}\text { Labelled } \\
\text { valve } \\
\text { size }\end{array}$} & $\begin{array}{c}\text { Overall } \\
\text { profile } \\
\text { height }\end{array}$ & $\begin{array}{c}\text { Outflow } \\
\text { profile } \\
\text { height }\end{array}$ & $\begin{array}{c}\text { Minimum } \\
\text { internal } \\
\text { diameter }\end{array}$ & $\begin{array}{c}\text { External } \\
\text { housing } \\
\text { diameter }\end{array}$ & $\begin{array}{c}\text { External } \\
\text { sewing ring } \\
\text { diameter }\end{array}$ \\
\cline { 2 - 6 } & (A) & (B) & (C) & (D) & (E) \\
\hline & & & & & \\
\hline
\end{tabular}

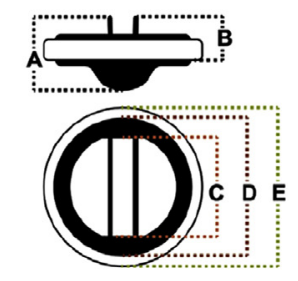

Mechanical valves, mitral position

\begin{tabular}{|c|c|c|c|c|c|}
\hline \multirow{4}{*}{$\begin{array}{c}\text { Labelled } \\
\text { valve } \\
\text { size }\end{array}$} & $\begin{array}{c}\text { Overall } \\
\text { profile } \\
\text { height }\end{array}$ & $\begin{array}{c}\text { Outflow } \\
\text { profile } \\
\text { height }\end{array}$ & $\begin{array}{c}\text { Minimum } \\
\text { internal } \\
\text { diameter }\end{array}$ & $\begin{array}{c}\text { External } \\
\text { housing } \\
\text { diameter }\end{array}$ & $\begin{array}{c}\text { External } \\
\text { sewing ring } \\
\text { diameter }\end{array}$ \\
\cline { 2 - 6 } & (A) & (B) & (C) & (D) & (E) \\
\hline & & & & & \\
\hline
\end{tabular}

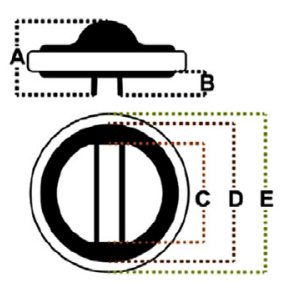

FIGURE 1. Standardized approach to present surgical heart valve physical dimensions: mechanical valves in the (A) aortic and (B) mitral position. The Task Force suggests that manufacturers use a complete, standardized set of physical dimensions and a standardized pictogram when describing their surgical heart valves. 
Bioprosthetic valves, aortic position

\begin{tabular}{|c|c|c|c|c|c|c|}
\hline \multirow{2}{*}{$\begin{array}{c}\text { Labelled } \\
\text { valve } \\
\text { size }\end{array}$} & $\begin{array}{c}\text { Overall } \\
\text { profile } \\
\text { height }\end{array}$ & $\begin{array}{c}\text { Outflow } \\
\text { profile } \\
\text { height }\end{array}$ & $\begin{array}{c}\text { Minimum } \\
\text { internal } \\
\text { diameter }\end{array}$ & $\begin{array}{c}\text { Internal } \\
\text { stent } \\
\text { diameter }\end{array}$ & $\begin{array}{c}\text { External } \\
\text { stent } \\
\text { diameter }\end{array}$ & $\begin{array}{c}\text { External } \\
\text { sewing ring } \\
\text { diameter }\end{array}$ \\
\cline { 2 - 7 } & (A) & (B) & (C) & (D) & (E) & (F) \\
\hline & & & & & & \\
\hline
\end{tabular}

Internally
mounted
leaflets
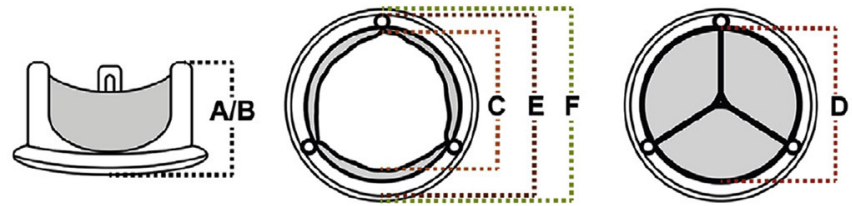

\section{Externally mounted} leaflets

A
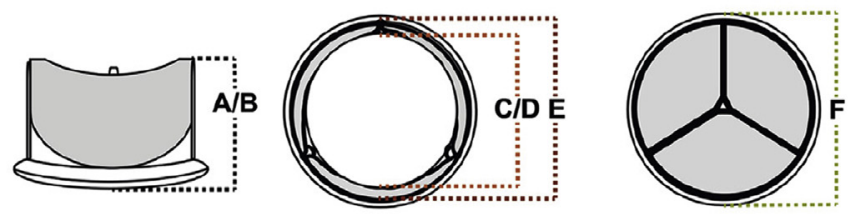

Bioprosthetic valves, mitral position

\begin{tabular}{|c|c|c|c|c|c|c|}
\hline \multirow{2}{*}{$\begin{array}{c}\text { Labelled } \\
\text { valve } \\
\text { size }\end{array}$} & \multicolumn{7}{|c|}{ Physical dimensions } \\
\cline { 2 - 7 } & $\begin{array}{c}\text { Overall } \\
\text { profile } \\
\text { height }\end{array}$ & $\begin{array}{c}\text { Outflow } \\
\text { profile } \\
\text { height }\end{array}$ & $\begin{array}{c}\text { Minimum } \\
\text { internal } \\
\text { diameter }\end{array}$ & $\begin{array}{c}\text { Internal } \\
\text { stent } \\
\text { diameter }\end{array}$ & $\begin{array}{c}\text { External } \\
\text { stent } \\
\text { diameter }\end{array}$ & $\begin{array}{c}\text { External } \\
\text { sewing ring } \\
\text { diameter }\end{array}$ \\
\cline { 2 - 8 } & (A) & (B) & (C) & (D) & (E) & (F) \\
\hline & & & & & & \\
\hline
\end{tabular}

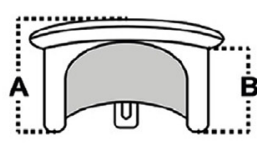

B
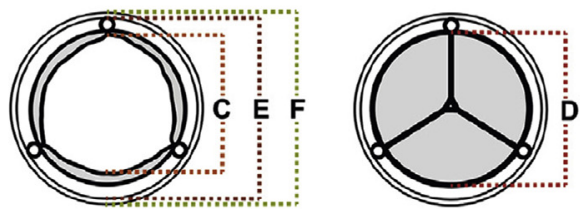

FIGURE 2. Standardized approach to present surgical heart valve physical dimensions: bioprosthetic valves in the (A) aortic and (B) mitral position.

valve size is defined as the "tissue annulus diameter of the patient into which the SHV is intended to be implanted' in the ISO 5840:2015 standard. ${ }^{3}$ In other words, labeled valve size reflects the manufacturer's recommendation into which annulus an SHV can be safely implanted. To emphasize that the actual meaning of 'labeled valve size' is 'patient tissue annulus diameter,' manufacturers should always present 'labeled valve size' as a separate variable when presenting the physical dimensions of SHVs. Surgeons should similarly realize that the corresponding valve size is simply a label, and not a true measure of the valve size.
It is not possible to design valves for each annulus size. Therefore, labeled valve sizes are practically representing tissue annulus diameter ranges, where a specific SHV is recommended to be implanted according to the manufacturer. $^{10,11}$ These ranges are defined by the valve-related tubular sizers. The lower margin of this range is the diameter of the largest valve-related tubular sizer that fits the annulus. The upper margin of this range is indirectly bordered by the diameter of the sizer 1 size larger (the sizer that does not fit).

It is sensible that the actual (numerical) labeled size of an SHV falls within these margins (Figure 5). ${ }^{12}$ However, as

TABLE 3. Current terminology used to describe annular attachment of SHVs, according to the ISO 5840:2015 standard

\begin{tabular}{ll}
\hline Term to describe sewing ring configuration & \multicolumn{1}{c}{ Definition provided in the ISO 5840:2015 standard } \\
\hline Intra-annular sewing ring & Sewing ring designed to secure the SHV 'wholly or mostly' within the patient's tissue annulus \\
Supra-annular sewing ring & Sewing ring designed to secure the valve 'wholly' above the patient's tissue annulus \\
\hline
\end{tabular}

ISO, International Organization for Standardization; SHV, surgical heart valve. 


\section{Mechanical valves}
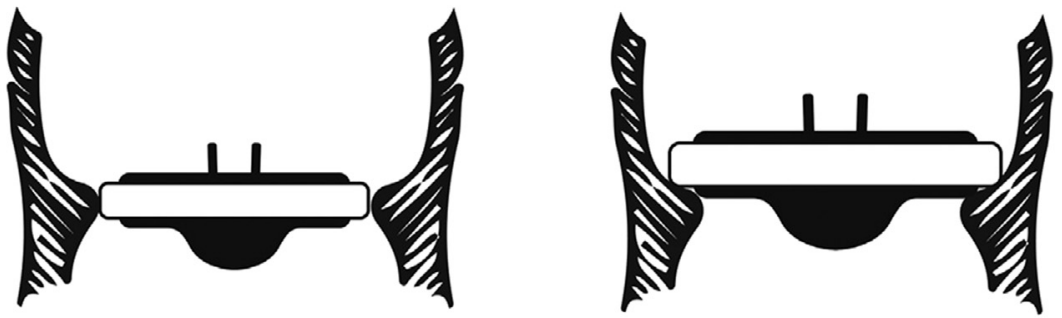

A

\section{Bioprosthetic valves}

B
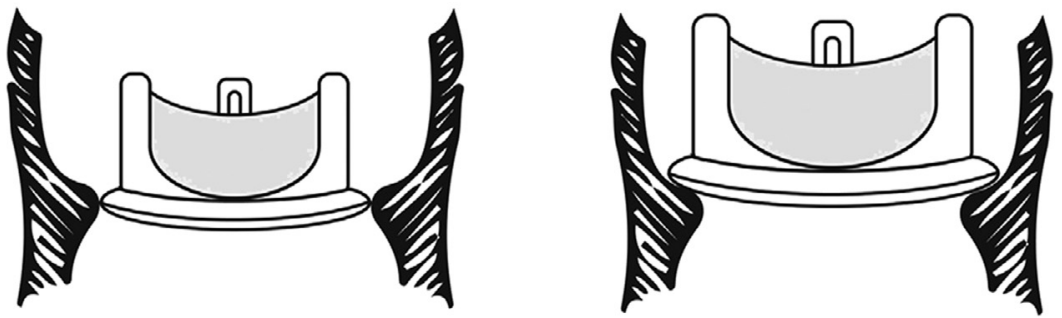

FIGURE 3. Example of standardized pictograms indicating the intended implant positions of (A) mechanical and (B) bioprosthetic surgical heart valves (SHV) in the aortic position. Considering the ambiguity of the current terminology used to describe the annular position of SHVs, the Task Force suggests that manufacturers use standardized pictograms to indicate the 'intended position(s)' of their SHVs related to the tissue annulus of the patient.

the margins of these tissue annulus ranges were not defined in the corresponding ISO standards, ${ }^{3}$ they can vary for different SHV models having the same labeled valve size (Figure 6). This historical lack of standardization renders the direct comparison of different SHVs based on labeled valve size impossible, precludes the exclusive use of a universal sizing tool, limits standard sizing and ultimately causes confusion in the surgical community. ${ }^{13}$

Redefining these 'tissue annulus ranges' belonging to specific labeled sizes would demand major changes in

\section{Mechanical valves}

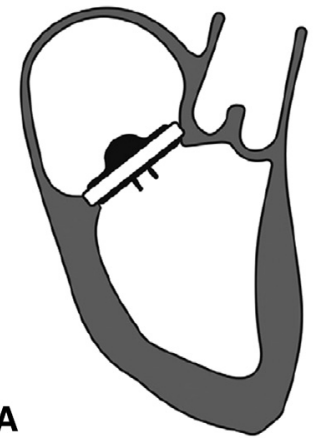

\section{Bioprosthetic valves}

B

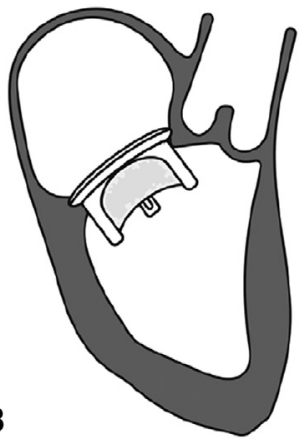

FIGURE 4. Example of standardized pictograms indicating the intended implant positions of (A) mechanical and (B) bioprosthetic surgical heart valves in the mitral position. Knowing the intended implant position of mitral surgical heart valves is important as these valves can potentially interfere with the mitral subvalvular apparatus, the left ventricular wall or the left ventricular outflow tract. existing SHV designs. For transparency, however, it is necessary to disclose the margins of these 'tissue annulus ranges.' This can easily be accomplished by disclosing the actual diameters of the tubular ends of the valverelated sizers and would clarify into which patients a specific SHV is 'intended to be implanted.'

Besides sizing with the cylindrical end of the valverelated sizer, the replica end of the sizer helps to determine the final fit and position of the SHV. Of note, the size of the replica can slightly differ from the actual dimensions of the corresponding SHV. This is due to the different properties of the sizer and SHV materials (mainly different flexibility, with a stiff sizer corresponding to a flexible SHV), and this should be considered during intraoperative sizing.

\section{PROVIDING INFORMATION ON PREDICTED HEMODYNAMIC PERFORMANCE}

Accurate and reliable information regarding the hemodynamic performance of an SHV after implantation is an important factor in optimal SHV choice. Also, comparison of measured and reference transprosthetic gradients and effective orifice area (EOA) values are used to assess SHV function during follow-up. ${ }^{14}$

Information on SHV hemodynamic performance can be obtained by benchtop in vitro measurements, by in vivo large animal studies and by using in vivo data from reference patient populations. Benchtop mock circulatory loops used for in vitro testing and animal models are not perfect substitutes of the human circulation, and results can be 


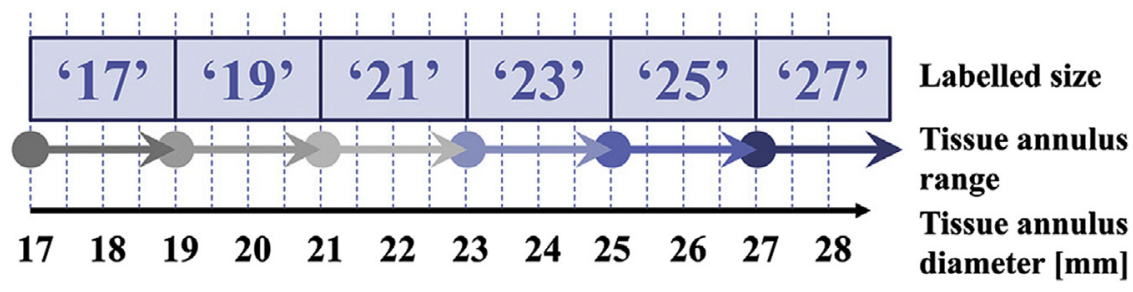

FIGURE 5. Ideal situation: well-defined, uniform relationship between labeled sizes and tissue annulus ranges. Comparing different surgical heart valve (SHV) models starts with selecting the valves that can be fitted into the same tissue annulus. A well-defined, uniform relationship between 'labeled valve size' and the 'tissue annulus range' where an SHV fits would allow direct comparison of SHVs based on labeled valve size.

influenced by differences in experimental protocols. ${ }^{15,16}$ Hence, in vitro hydrodynamic data or data from animal experiments should not be used to characterize or predict hemodynamic performance of SHVs in a clinical setting. In vivo data, derived from Doppler echocardiography measurements, performed in a reference patient population, should be the primary source to predict the hemodynamic performance of an SHV after implantation. ${ }^{4,17}$

Transprosthetic gradients and EOA do not solely depend on the physical features of an SHV. Doppler echocardiography measurements are influenced by the anatomy (upstream and downstream of the prosthesis) and the physiological state (heart rate, myocardial function or cardiac output) of the individual patient receiving an SHV implant. Furthermore, surgical implantation technique and the timing between surgery and echocardiography ${ }^{18,19}$ can also potentially affect Doppler parameters, ${ }^{8}$ introducing variability into the results. In vivo EOA reference values follow a normal distribution (Figure 7) ${ }^{20}$ and should always be described with a mean value and its standard deviation (SD). Theoretically, the variability (described by the SD of the mean) can be reduced by increasing the number of patients, standardizing Doppler echocardiography protocols and performing measurements in independent reference laboratories (core laboratories).

To characterize the hemodynamic performance of a specific SHV model, 'mean transprosthetic gradients' and 'EOAs' determined by Doppler echocardiography should be used. Echocardiography used to determine normal reference values should be performed between 30 days and 1 year after implantation and in a minimum of 30 patients for each labeled size. Data should be presented as mean \pm SD for each SHV model and labeled size, along with source study details (eg, study characteristics, number of patients investigated, mean \pm SD age, mean \pm SD body mass index [BMI] and mean \pm SD body surface area [BSA] of patients, per labeled size), indicating whether the measurements were performed in an independent core laboratory or not. Whenever possible, only core laboratory adjudicated data should be used.

\section{PREDICTING THE PROBABILITY OF PROSTHESIS-PATIENT MISMATCH AFTER AORTIC VALVE REPLACEMENT}

PPM is manifested by high transprosthetic gradients through an otherwise normally functioning SHV. PPM results from the orifice of the implanted SHV being too small to fulfil the patient's cardiac output requirements. ${ }^{21}$ The size of the SHV orifice relative to the patient is characterized by the 'indexed EOA,' which is calculated by dividing the EOA of the SHV by the BSA of the patient:

$$
\text { Indexed EOA }\left(\mathrm{cm}^{2} / \mathrm{m}^{2}\right)=\frac{\text { EOA }\left(\mathrm{cm}^{2}\right)}{\text { BSA of the patient }\left(\mathrm{m}^{2}\right)} \text {. }
$$

PPM is associated with a higher risk of poor outcomes after aortic valve replacement, ${ }^{22,23}$ and its prevention is of paramount importance when selecting an SHV for implantation. ${ }^{24}$ Cut-off levels of indexed EOA have been introduced to define moderate and severe PPM after aortic valve replacement. ${ }^{14}$

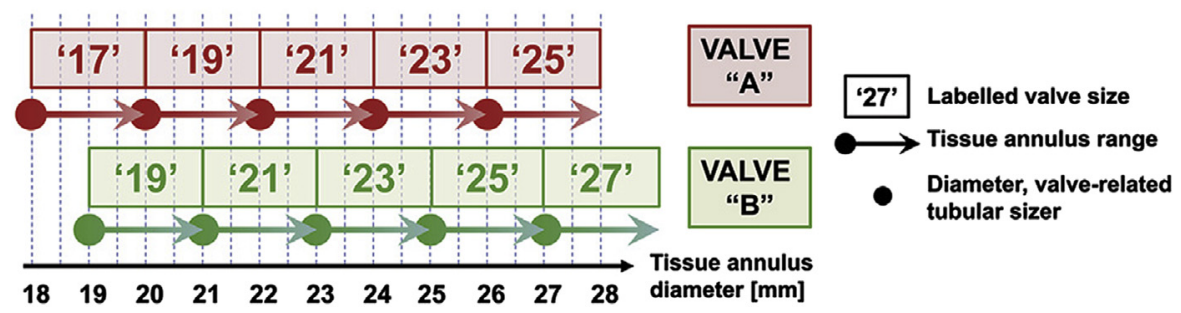

FIGURE 6. Actual situation: the margins of 'tissue annulus ranges' belonging to specific labeled valve sizes are not defined. The margins of 'tissue annulus ranges' are not standardized and can be different for similarly labeled surgical heart valve models. This lack of standardization precludes direct comparability based on labeled valve size and the use of a universal sizing tool. 


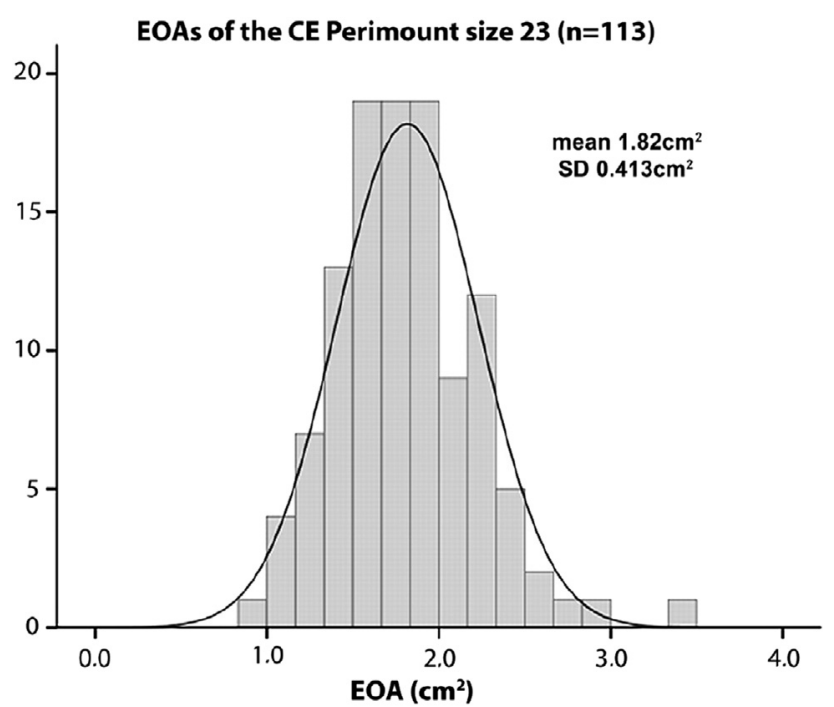

FIGURE 7. Distribution of the 'reference EOA' of a 23-mm bioprosthetic valve. In vivo reference EOAs of surgical heart valves (SHVs) are determined in reference patient populations and are influenced not only by SHV characteristics but also by patient anatomy and physiology. Reference EOAs have a normal distribution, described by a mean EOA and its SD. $E O A$, Effective orifice area. (Reproduced from ${ }^{20}$ with permission from BMJ Publishing Group Ltd.)

To predict PPM after SHV implantation, valve manufacturers provide 'indexed EOA charts.' The main principle of these charts is that by using a 'reference EOA' and the BSA of the patient, the 'expected indexed EOA' after implantation can be calculated and compared to the pre-defined PPM cut-off levels.

Expected indexed EOA $\left(\mathrm{cm}^{2} / \mathrm{m}^{2}\right)=$

$$
\frac{\text { Reference EOA }\left(\mathrm{cm}^{2}\right)}{\text { BSA of the patient }\left(\mathrm{m}^{2}\right)} \text {. }
$$

Theoretically, this would make the selection of a large enough SHV, and thereby the prevention of PPM, possible. In 'indexed EOA charts' provided by valve manufacturers, expected indexed EOA values are typically color-coded as follows: 'green - above PPM cut-off level,' 'yellow-moderate PPM' and 'red-severe PPM.' However, PPM charts provided by valve manufacturers have been severely criticized for their inaccuracy. ${ }^{25}$ Due to the lack of standardization, the use of different PPM cut-offs and the questionable quality of their reference EOAs, these charts are regarded by many as marketing tools rather than useful clinical assets. ${ }^{26}$

Standardized PPM charts, however, would (1) help surgeons in objectively assessing the probability of PPM before SHV implantation; (2) facilitate optimal SHV choice; and (3) prevent biased comparisons between different SHVs. ${ }^{26}$ Therefore, the Task Force proposes that manufacturers provide standardized charts for their aortic SHVs to predict the probability of severe PPM after implantation.

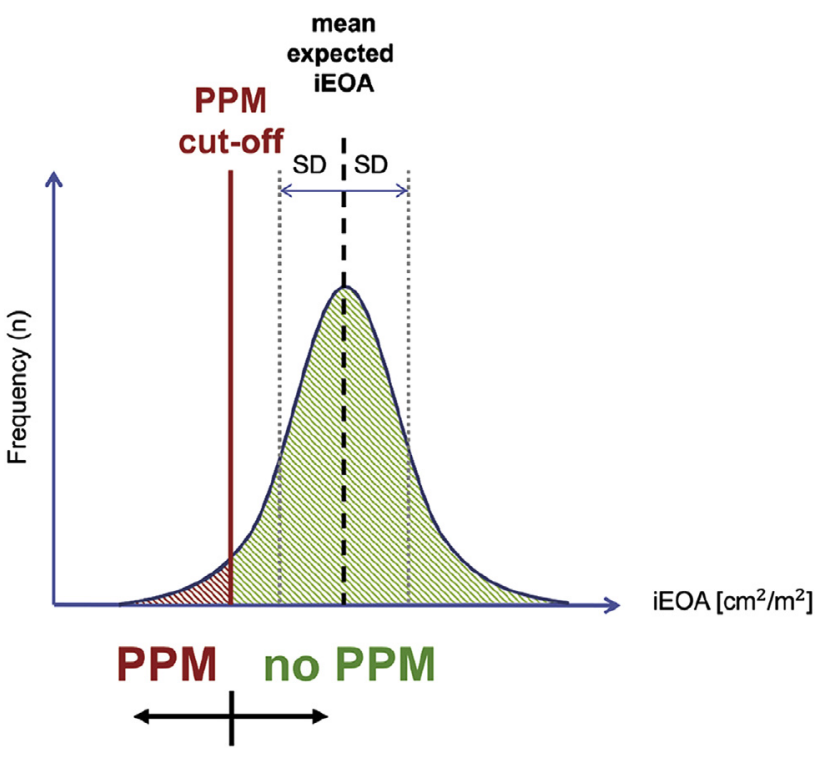

FIGURE 8. Applying PPM cut-off to the 'expected indexed EOA' distribution, to calculate PPM probability. Applying a PPM cut-off value to the 'expected indexed EOA' distribution helps assessing the 'percentage probability' of PPM after surgical heart valve implantation. This method can provide a better understanding of the actual PPM risk and avoid the shortcomings of classifying predicted PPM into a 'yes/no,' binary variable. $i E O A$, Indexed effective orifice area; $P P M$, prosthesis-patient mismatch.

To create a 'standardized PPM chart,' the following is required: (1) high-quality reference EOA values for all SHV models and sizes from a reliable source; (2) the use of uniform PPM cut-off levels; and (3) a tool to accurately predict the probability of PPM after SHV implantation.

The use of reliable, high-quality reference EOA values is of paramount importance. In PPM charts, reference EOA values derived from large prospective multicentre clinical studies with standardized core laboratory echocardiography assessment should be used, if possible. Data from at least 30 patients should be available to determine the mean $\pm \mathrm{SD}$ reference EOA, for each SHV model and labeled size. In addition, the following study details should be provided on the standardized PPM chart: sample size per labeled SHV size, study characteristics (prospective or retrospective, period of patient inclusion, single or multicentre, regulatory study or not) and whether echocardiography was assessed in a core laboratory.

The use of uniform indexed EOA cut-offs is mandatory to define PPM after aortic valve replacement. Recent guidelines advocate adjusting PPM cut-offs for the BMI of the patient. ${ }^{14}$ In the standardized charts, the following PPM cutoff values should be used: for non-obese (BMI $<30 \mathrm{~kg} /$ $\mathrm{m}^{2}$ ) patients, severe PPM should be defined as an indexed EOA of $<0.65 \mathrm{~cm}^{2} / \mathrm{m}^{2}$; while for patients with BMI $\geq 30$ $\mathrm{kg} / \mathrm{m}^{2}$, severe PPM should be defined as an indexed EOA of $\leq 0.55 \mathrm{~cm}^{2} / \mathrm{m}^{2}$. ${ }^{14}$

Instead of classifying PPM simply into a 'yes/no' (binary) variable, knowing the exact probability of severe 


\begin{tabular}{|c|c|c|c|c|c|c|c|c|c|c|c|c|c|}
\hline \multicolumn{14}{|c|}{$\begin{array}{r}\text { Probability of severe* } \\
\text { Prosthesis-Patient Mismatch } \\
\text { "MANUFACTURER" - "VALVE MODEL" }\end{array}$} \\
\hline \multicolumn{2}{|c|}{$\begin{array}{c}\text { Labelled valve } \\
\text { size }\end{array}$} & \multicolumn{2}{|c|}{19} & \multicolumn{2}{|c|}{21} & \multicolumn{2}{|c|}{23} & \multicolumn{2}{|c|}{25} & \multicolumn{2}{|c|}{27} & \multicolumn{2}{|c|}{29} \\
\hline \multicolumn{2}{|c|}{$\begin{array}{c}\text { Patient BMI } \\
{\left[\mathrm{kg} / \mathrm{m}^{2}\right]}\end{array}$} & $<30$ & $\geq 30$ & $<30$ & $\geq 30$ & $<30$ & $\geq 30$ & $<30$ & $\geq 30$ & $<30$ & $\geq 30$ & \multirow{2}{*}{\begin{tabular}{|c|}
$<30$ \\
$0 \%$ \\
\end{tabular}} & \multirow{2}{*}{\begin{tabular}{|l|}
$\geq 30$ \\
$0 \%$ \\
\end{tabular}} \\
\hline \multirow{14}{*}{ ع } & 1.2 & $9 \%$ & $3 \%$ & $7 \%$ & $4 \%$ & $4 \%$ & $3 \%$ & $2 \%$ & $1 \%$ & $1 \%$ & $1 \%$ & & \\
\hline & 1.3 & $16 \%$ & $7 \%$ & $12 \%$ & $7 \%$ & $7 \%$ & $4 \%$ & $3 \%$ & $2 \%$ & $2 \%$ & $1 \%$ & $0 \%$ & $0 \%$ \\
\hline & 1.4 & $25 \%$ & $12 \%$ & $18 \%$ & $10 \%$ & $11 \%$ & $7 \%$ & $6 \%$ & $3 \%$ & $3 \%$ & $2 \%$ & $0 \%$ & $0 \%$ \\
\hline & 1.5 & $34 \%$ & $18 \%$ & $24 \%$ & $15 \%$ & $15 \%$ & $10 \%$ & $8 \%$ & $5 \%$ & $5 \%$ & $3 \%$ & $0 \%$ & $0 \%$ \\
\hline & 1.6 & $43 \%$ & $25 \%$ & $29 \%$ & $19 \%$ & $19 \%$ & $13 \%$ & $12 \%$ & $8 \%$ & $7 \%$ & $5 \%$ & $0 \%$ & $0 \%$ \\
\hline & 1.7 & $51 \%$ & $31 \%$ & $35 \%$ & $24 \%$ & $23 \%$ & $16 \%$ & $15 \%$ & $10 \%$ & $10 \%$ & $7 \%$ & $0 \%$ & $0 \%$ \\
\hline & 1.8 & $58 \%$ & $38 \%$ & $40 \%$ & $28 \%$ & $28 \%$ & $20 \%$ & $19 \%$ & $13 \%$ & $13 \%$ & $9 \%$ & $0 \%$ & $0 \%$ \\
\hline & 1.9 & $64 \%$ & $44 \%$ & $45 \%$ & $33 \%$ & $32 \%$ & $23 \%$ & $23 \%$ & $16 \%$ & $15 \%$ & $11 \%$ & $0 \%$ & $0 \%$ \\
\hline & 2.0 & $69 \%$ & $50 \%$ & $50 \%$ & $37 \%$ & $35 \%$ & $27 \%$ & $27 \%$ & $19 \%$ & $18 \%$ & $14 \%$ & $1 \%$ & $0 \%$ \\
\hline & 2.1 & $74 \%$ & $55 \%$ & $54 \%$ & $41 \%$ & $39 \%$ & $30 \%$ & $30 \%$ & $22 \%$ & $21 \%$ & $16 \%$ & $1 \%$ & $0 \%$ \\
\hline & 2.2 & $77 \%$ & $60 \%$ & $58 \%$ & $45 \%$ & $42 \%$ & $33 \%$ & $34 \%$ & $25 \%$ & $24 \%$ & $18 \%$ & $2 \%$ & $1 \%$ \\
\hline & 2.3 & $80 \%$ & $64 \%$ & $61 \%$ & $48 \%$ & $45 \%$ & $36 \%$ & $37 \%$ & $28 \%$ & $27 \%$ & $21 \%$ & $3 \%$ & $1 \%$ \\
\hline & 2.4 & $83 \%$ & $68 \%$ & $64 \%$ & $51 \%$ & $48 \%$ & $39 \%$ & $40 \%$ & $31 \%$ & $30 \%$ & $23 \%$ & $4 \%$ & $2 \%$ \\
\hline & 2.5 & $85 \%$ & $71 \%$ & $67 \%$ & $54 \%$ & $51 \%$ & $41 \%$ & $43 \%$ & $34 \%$ & $32 \%$ & $25 \%$ & $6 \%$ & $3 \%$ \\
\hline \multirow{9}{*}{ 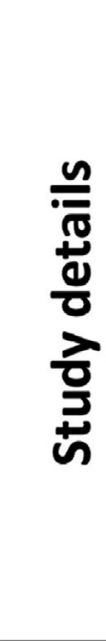 } & $\begin{array}{c}\mathrm{EOA}, \operatorname{mean} \pm \mathrm{SD} \\
{\left[\mathrm{cm}^{2}\right]}\end{array}$ & $1.1 \pm$ & 0.2 & $1.3 \pm$ & 0.3 & $1.6 \pm$ & 0.4 & $1.8 \pm$ & 0.4 & $2.2 \pm$ & 0.5 & $2.8 \pm$ & 0.3 \\
\hline & $\begin{array}{l}\text { Patients per } \\
\text { valve size }(n)\end{array}$ & \multicolumn{2}{|c|}{25} & \multicolumn{2}{|c|}{52} & \multicolumn{2}{|c|}{79} & \multicolumn{2}{|c|}{65} & \multicolumn{2}{|c|}{43} & \multicolumn{2}{|c|}{32} \\
\hline & Prospective & \multicolumn{2}{|c|}{ yes } & \multicolumn{2}{|c|}{ yes } & \multicolumn{2}{|c|}{ yes } & \multicolumn{2}{|c|}{ yes } & \multicolumn{2}{|c|}{ yes } & \multicolumn{2}{|c|}{ yes } \\
\hline & $\begin{array}{c}\text { Centers per } \\
\text { valve size (n) }\end{array}$ & \multicolumn{2}{|c|}{3} & \multicolumn{2}{|c|}{3} & \multicolumn{2}{|c|}{3} & 3 & $B$ & 3 & & 3 & \\
\hline & Pooled data & no & & $\mathrm{n}$ & & & & $\mathrm{nc}$ & 0 & no & & no & \\
\hline & Regulatory & no & & $\mathrm{n}$ & & & & no & 0 & no & & no & \\
\hline & Echo core lab & ye & & ye & & & & ye & es & ye & & ye & \\
\hline & $\begin{array}{c}\text { Period of data } \\
\text { collection }\end{array}$ & $2012-$ & 2014 & 2012 & 2014 & 2012 & 2014 & $2012-$ & -2014 & $2012-$ & 2014 & $2012-$ & 2014 \\
\hline & \begin{tabular}{|c|} 
Timing of postop \\
echo
\end{tabular} & $3 \mathrm{mor}$ & ths & $3 \mathrm{mo}$ & nths & $3 \mathrm{mc}$ & nths & $3 \mathrm{~mol}$ & nths & $3 \mathrm{mo}$ & nths & $3 \mathrm{mo}$ & inths \\
\hline *severe & is defined as iEO & $A: \leq 0.65 c$ & $2 / m^{2}$, in & atients & th $\mathrm{BN}$ & $<30 \mathrm{~kg} /$ & $\overline{n^{2} ; a n}$ & iEOA: & $\leq 0.55$ & $1^{2} / m^{2}$ in $p$ & jatient & with BMI & $\geq 30$ \\
\hline $\begin{array}{l}\text { COLOR } \\
\text { indexec }\end{array}$ & $\begin{array}{l}\text { NG: yellow indica } \\
\text { is below the seve }\end{array}$ & $\begin{array}{l}\text { s that th } \\
\text { e PPM cu }\end{array}$ & $\begin{array}{l}\text { e percen } \\
\text { toff leve }\end{array}$ & ge prob & bility & severe I & $\mathrm{PM}$ is & ater thar & in or e & al to $50 \%$ & mean & g that the & e mean \\
\hline
\end{tabular}

FIGURE 9. Standardized PPM chart for surgical heart valves in the aortic position. Standardized PPM charts provide the percentage probability of severe PPM after implantation of an aortic surgical heart valve into a specific patient. Different cut-offs of severe PPM are used for non-obese (BMI) and obese (BMI) patients. The probability of severe PPM is calculated using the distribution of 'reference EOAs,' 'patient BSA' and the 'BMI-adjusted severe PPM cut-off.' The yellow color indicates that the 'mean expected indexed EOA' is under the PPM cut-off (percentage probability is larger than 50\%). BMI, Body mass index; $B S A$, body surface area; $E O A$, effective orifice area; $P P M$, prosthesis-patient mismatch; $i E O A$, indexed effective orifice area. 
PPM is more useful in clinical decision-making. The standardized PPM chart should therefore provide the 'probability of severe PPM' for a given patient in percentages, based on the reference EOA of the corresponding SHV (described as mean $\pm \mathrm{SD}$ ) and on the BMI and BSA of the patient.

Expected indexed EOAs are derived from reference EOAs. Hence, expected indexed EOA values follow the same distribution as reference EOA values. When applying the above-mentioned severe PPM cut-offs to this distribution, the exact probability of PPM can be calculated (Figure 8). Dividing the area under the curve below the PPM limit by the area under the curve of the whole "expected indexed EOA distribution' gives us the probability of severe PPM:

PPM probability =

\section{AUC 'below PPM limit'}

AUC 'expected indexed EOA distribution'
In standardized PPM charts, the probability of PPM should be provided using this method. PPM probability should be provided in percentages, for BSA ranges between 1.3 and $2.6 \mathrm{~m}^{2}$, in $0.1 \mathrm{~m}^{2}$ increments. $^{27}$

To emphasize that PPM after aortic valve replacement is not only dependent on the characteristics of the SHV or on the BMI and BSA of the patient, the standardized PPM chart should contain the following disclaimer: 'This chart is a support tool to estimate the probability of PPM in patients undergoing aortic valve replacement with a particular prosthetic heart valve, but the actual risk further depends on specific patient characteristics and operative technique.' An example of the proposed standardized PPM chart is provided in Figure 9.

\section{PROVIDING INFORMATION FOR AN OPTIMAL SURGICAL HEART VALVE CHOICE}

To facilitate SHV choice, the Task Force identified the following essential information regarding SHV

\section{AORTIC}

\begin{tabular}{|c|c|c|c|c|c|c|c|c|c|c|c|c|c|}
\hline \multicolumn{14}{|c|}{$\begin{array}{c}\text { Probability of severe* } \\
\text { Prosthesis-Patient Mismatch }\end{array}$} \\
\hline \multicolumn{14}{|c|}{ "MANUFACTURER" - "VALVE MODEL" } \\
\hline \multicolumn{2}{|c|}{$\begin{array}{l}\text { Labelled valve } \\
\text { size }\end{array}$} & \multicolumn{2}{|c|}{19} & \multicolumn{2}{|c|}{21} & \multicolumn{2}{|c|}{23} & \multicolumn{2}{|c|}{25} & \multicolumn{2}{|c|}{27} & \multicolumn{2}{|c|}{29} \\
\hline \multicolumn{2}{|c|}{$\begin{array}{c}\text { Patient BMI } \\
{\left[\mathrm{kg} / \mathrm{m}^{2}\right]}\end{array}$} & $<30$ & $\geq 30$ & $<30$ & $\geq 30$ & $<30$ & $\geq 30$ & $<30$ & $\geq 30$ & $<30$ & $\geq 30$ & $<30$ & $\geq 30$ \\
\hline \multirow{14}{*}{ 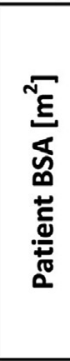 } & 1.2 & $9 \%$ & $3 \%$ & $7 \%$ & $4 \%$ & $4 \%$ & $3 \%$ & $2 \%$ & $1 \%$ & $1 \%$ & $1 \%$ & $0 \%$ & $0 \%$ \\
\hline & 1.3 & $16 \%$ & $7 \%$ & $12 \%$ & $7 \%$ & $7 \%$ & $4 \%$ & $3 \%$ & $2 \%$ & $2 \%$ & $1 \%$ & $0 \%$ & $0 \%$ \\
\hline & 1.4 & $25 \%$ & $12 \%$ & $18 \%$ & $10 \%$ & $11 \%$ & $7 \%$ & $6 \%$ & $3 \%$ & $3 \%$ & $2 \%$ & $0 \%$ & $0 \%$ \\
\hline & 1.5 & $34 \%$ & $18 \%$ & $24 \%$ & $15 \%$ & $15 \%$ & $10 \%$ & $8 \%$ & $5 \%$ & $5 \%$ & $3 \%$ & $0 \%$ & $0 \%$ \\
\hline & 1.6 & $43 \%$ & $25 \%$ & $29 \%$ & $19 \%$ & $19 \%$ & $13 \%$ & $12 \%$ & $8 \%$ & $7 \%$ & $5 \%$ & $0 \%$ & $0 \%$ \\
\hline & 1.7 & $51 \%$ & $31 \%$ & $35 \%$ & $24 \%$ & $23 \%$ & $16 \%$ & $15 \%$ & $10 \%$ & $10 \%$ & $7 \%$ & $0 \%$ & $0 \%$ \\
\hline & 1.8 & $58 \%$ & $38 \%$ & $40 \%$ & $28 \%$ & $28 \%$ & $20 \%$ & $19 \%$ & $13 \%$ & $13 \%$ & $9 \%$ & $0 \%$ & $0 \%$ \\
\hline & 1.9 & $64 \%$ & $44 \%$ & $45 \%$ & $33 \%$ & $32 \%$ & $23 \%$ & $23 \%$ & $16 \%$ & $15 \%$ & $11 \%$ & $0 \%$ & $0 \%$ \\
\hline & 2.0 & $69 \%$ & $50 \%$ & $50 \%$ & $37 \%$ & $35 \%$ & $27 \%$ & $27 \%$ & $19 \%$ & $18 \%$ & $14 \%$ & $1 \%$ & $0 \%$ \\
\hline & 2.1 & $74 \%$ & $55 \%$ & $54 \%$ & $41 \%$ & $39 \%$ & $30 \%$ & $30 \%$ & $22 \%$ & $21 \%$ & $16 \%$ & $1 \%$ & $0 \%$ \\
\hline & 2.2 & $77 \%$ & $60 \%$ & $58 \%$ & $45 \%$ & $42 \%$ & $33 \%$ & $34 \%$ & $25 \%$ & $24 \%$ & $18 \%$ & $2 \%$ & $1 \%$ \\
\hline & 2.3 & $80 \%$ & $64 \%$ & $61 \%$ & $48 \%$ & $45 \%$ & $36 \%$ & $37 \%$ & $28 \%$ & $27 \%$ & $21 \%$ & $3 \%$ & $1 \%$ \\
\hline & 2.4 & $83 \%$ & $68 \%$ & $64 \%$ & $51 \%$ & $48 \%$ & $39 \%$ & $40 \%$ & $31 \%$ & $30 \%$ & $23 \%$ & $4 \%$ & $2 \%$ \\
\hline & 2.5 & $85 \%$ & $71 \%$ & $67 \%$ & $54 \%$ & $51 \%$ & $41 \%$ & $43 \%$ & $34 \%$ & $32 \%$ & $25 \%$ & $6 \%$ & $3 \%$ \\
\hline \multirow{9}{*}{ 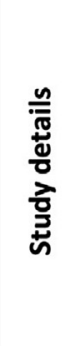 } & $\begin{array}{c}\text { EOA, meantSD } \\
{\left[\mathrm{cm}^{2}\right]}\end{array}$ & $1.1 \pm$ & 0.2 & $1.3 \pm$ & 0.3 & $1.6 \pm$ & 0.4 & $1.8 \pm$ & 0.4 & $2.2 \pm$ & 0.5 & $2.8 \pm$ & 0.3 \\
\hline & $\begin{array}{l}\text { Patients per } \\
\text { valve size (n) }\end{array}$ & \multicolumn{2}{|c|}{25} & \multicolumn{2}{|c|}{52} & \multicolumn{2}{|c|}{79} & \multicolumn{2}{|c|}{65} & \multicolumn{2}{|c|}{43} & \multicolumn{2}{|c|}{32} \\
\hline & Prospective & \multicolumn{2}{|c|}{ yes } & \multicolumn{2}{|c|}{ yes } & \multicolumn{2}{|c|}{ yes } & \multicolumn{2}{|c|}{ yes } & \multicolumn{2}{|c|}{ yes } & \multicolumn{2}{|c|}{ yes } \\
\hline & $\begin{array}{l}\text { Centers per } \\
\text { valve size (n) }\end{array}$ & \multicolumn{2}{|c|}{3} & \multicolumn{2}{|c|}{3} & \multicolumn{2}{|c|}{3} & \multicolumn{2}{|c|}{3} & 3 & 3 & 3 & \\
\hline & Pooled data & no & & no & & no & o & & no & no & o & $\mathrm{nc}$ & \\
\hline & Regulatory & no & & no & & no & 10 & $\mathrm{nc}$ & to & no & o & $\mathrm{nc}$ & \\
\hline & Echo core lab & ye & & yes & & yes & es & ye & es & yes & es & ye & \\
\hline & $\begin{array}{c}\text { Period of data } \\
\text { collection }\end{array}$ & 2012 . & 2014 & $2012-$ & 2014 & 2012 - & -2014 & 2012 . & -2014 & 2012 - & -2014 & 2012 - & -2014 \\
\hline & $\begin{array}{l}\text { Timing of } \\
\text { postop echo }\end{array}$ & $3 \mathrm{mor}$ & nths & $3 \mathrm{mon}$ & & $3 \mathrm{mon}$ & onths & $3 \mathrm{mo}$ & onths & $3 \mathrm{mor}$ & onths & $3 \mathrm{mo}$ & onths \\
\hline *severe PP & is defined as $\mathrm{EEO}$ & $A: \leq 0.65 \mathrm{cn}$ & $\mathrm{m}^{2} / \mathrm{m}^{2}$, ir & a patients & with BMI & $\|<30 \mathrm{~kg} / \mathrm{m}$ & $\mathrm{m}^{2}$; and a & as IEOA: & $\leq 0.55 \mathrm{~cm}$ & $2^{2} / m^{2}$ in $p$ & patients & with BMI & 1230 \\
\hline $\begin{array}{l}\text { ILORC } \\
\text { lexed }\end{array}$ & $\begin{array}{l}\text { yellow indicat } \\
\text { below the seve }\end{array}$ & $\begin{array}{l}\text { as that th } \\
\text { ere PPM cu }\end{array}$ & $\begin{array}{l}\text { e percen } \\
\text { toff leve }\end{array}$ & e proba & ability of & $f$ severe PF & PM is gre & eater thar & an ore & al to $50 \%$, & 6 mea & ng that th & ne mean \\
\hline
\end{tabular}

This chart is developed according to the standardized criteria of the Valve Labelling Task Force

\begin{tabular}{|c|c|c|c|c|c|c|}
\hline \multicolumn{7}{|c|}{ Possible implant positions } \\
\hline \multirow{3}{*}{$\begin{array}{l}\text { Labelled } \\
\text { valve size }\end{array}$} & \multicolumn{6}{|c|}{ Physical dimensions } \\
\hline & $\begin{array}{c}\begin{array}{c}\text { Overall } \\
\text { profile } \\
\text { height } \\
\text { [mm] }\end{array} \\
\end{array}$ & $\begin{array}{c}\begin{array}{c}\text { Outflow } \\
\text { profile } \\
\text { height } \\
\text { [mm] }\end{array} \\
\end{array}$ & $\begin{array}{c}\begin{array}{c}\text { Minimum } \\
\text { internal } \\
\text { diameter } \\
{[\mathrm{mm}]}\end{array} \\
\end{array}$ & $\begin{array}{c}\begin{array}{c}\text { Internal } \\
\text { stent } \\
\text { diameter } \\
\text { [mm] }\end{array} \\
\end{array}$ & $\begin{array}{c}\text { External } \\
\text { stent } \\
\text { diameter } \\
\text { [mm] } \\
\end{array}$ & $\begin{array}{c}\text { External } \\
\text { sewing ring } \\
\text { diameter } \\
{[\mathrm{mm}]} \\
\end{array}$ \\
\hline & (A) & (B) & (C) & (D) & (E) & (F) \\
\hline 19 & 13 & 13 & 17.1 & 18 & 19.2 & 24 \\
\hline 21 & 14 & 14 & 19.2 & 20 & 21.2 & 26 \\
\hline 23 & 15 & 15 & 21.2 & 22 & 23.2 & 28 \\
\hline 25 & 16 & 16 & 23.2 & 24 & 25.3 & 30 \\
\hline 27 & 17 & 17 & 25.2 & 26 & 27.3 & 32 \\
\hline 29 & 18 & 18 & 27.2 & 28 & 29.3 & 34 \\
\hline
\end{tabular}

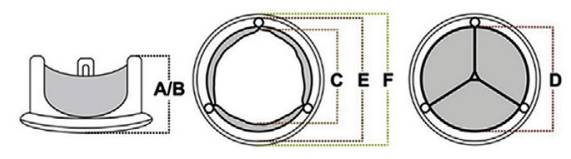

\begin{tabular}{|c|c|c|c|c|c|c|}
\hline \multicolumn{7}{|c|}{$\begin{array}{l}\text { Labelled valve size and sizer diameters, } \\
\text { defining tissue annulus ranges where specific sizes fit }\end{array}$} \\
\hline Lab & 19 & 21 & 23 & 25 & 27 & 29 \\
\hline $\begin{array}{r}\text { Diameter, valve re } \\
{[\mathrm{m}}\end{array}$ & 18.3 & 20.2 & 22.4 & 24.5 & 26.1 & 28.2 \\
\hline \multicolumn{7}{|c|}{$\begin{array}{l}\text { DISCLAIMER: Besides tissue annulus diameter, other factors (e.g. patient's anatomy, extent of } \\
\text { annular debridement, annular positioning, sewing cuff properties, prosthesis height, surgeon's } \\
\text { sizing and suturing technique and sizing before or after placing the annular sutures) can influence } \\
\text { the final fit of the prosthesis and should be considered during clinical sizing. }\end{array}$} \\
\hline
\end{tabular}

FIGURE 10. Standardized Valve Chart: aortic valves. Standardized Valve Charts provide essential information on surgical heart valve (SHV) characteristics in a uniform manner and allow for comparability between different SHV models without demanding radical changes in current SHV designs or labelling. Furthermore, Valve Charts highlight the necessity of considering multiple factors when selecting an SHV for implantation. BMI, Body mass index; $B S A$, body surface area; $E O A$, effective orifice area; $i E O A$, indexed effective orifice area; $P P M$, prosthesis-patient mismatch. 
characteristics that should be made easily available by valve manufacturers, for all SHV models and sizes: (1) SHV 'physical dimensions,' presented in a complete and standardized way; (2) 'tissue annulus ranges' in which SHVs can be implanted, characterized by the diameters of the valve-related tubular sizers; (3) a standardized 'pictogram indicating the intended position of the SHV' after implantation, related to the patient tissue annulus; (4) 'high-quality reference EOA values'; and (5) for aortic SHVs, a 'standardized chart to display the probability of severe PPM,' based on high-quality in vivo reference EOAs, using standardized, BMI-adjusted PPM cut-offs, for realistic patient BSA ranges.

Although final SHV choice is typically made in the operating theatre, surgeons should be provided with all necessary information required for optimal SHV choice well before the operation. Currently, medical literature, marketing materials provided by valve manufacturers, package labels and instructions for use booklets are the primary sources of information regarding SHV characteristics. ${ }^{4}$ The main purpose of package labels is to allow easy identification of the product for the end-user, and throughout the whole supply chain. Furthermore, labels must contain essential information regarding sterility, manufacturing and the intended use of the product. However, it is not possible to provide all information regarding SHV characteristics required for valve selection on package labels. On the other hand, instructions for use booklets are typically only accessible after opening the packaging of the SHV and, from a practical standpoint, it is not possible to study these booklets in detail in the time-pressured environment of an operating theatre, during intraoperative SHV implantation.

Therefore, instead of changing existing package labels, the Task Force suggests the introduction and the use of a standardized Valve Chart, to provide comprehensive information regarding SHV characteristics. Standardized Valve Charts should be provided by manufacturers and should contain the following information: (1) manufacturer name and type of the SHV; (2) standardized table and pictogram to present SHV physical dimensions; (3) sizer dimensions to indicate the tissue annulus ranges where the SHVs can be fitted; (4) standardized pictogram indicating the intended implant position of the SHV; and (5) standardized PPM chart to predict the probability of PPM, for SHVs used in

MITRAL

Valve chart for "VALVE" by "MANUFACTURER"

This chart is developed according to the standardized criteria of the EACTS-STS-AATS

\begin{tabular}{|c|c|c|c|c|c|}
\hline \multicolumn{6}{|c|}{ In vivo hemodynamic performance } \\
\hline \multicolumn{6}{|c|}{ "MANUFACTURER" - "VALVE MODEL" } \\
\hline \multirow{2}{*}{\multicolumn{2}{|c|}{$\begin{array}{c}\text { Labelled valve } \\
\text { size }\end{array}$}} & 27 & 29 & 31 & 33 \\
\hline & & $2.2 \pm 0.2$ & $2.7 \pm 0.3$ & $2.8 \pm 0.4$ & $3.1 \pm 0.5$ \\
\hline \multirow{8}{*}{$\begin{array}{l}\frac{n}{0} \\
\frac{0}{0} \\
\frac{2}{2} \\
\frac{2}{3}\end{array}$} & $\begin{array}{l}\text { Patients per } \\
\text { valve size }(n)\end{array}$ & 21 & 25 & 42 & 44 \\
\hline & Prospective & no & no & no & no \\
\hline & $\begin{array}{l}\text { Centers per } \\
\text { valve size ( } \mathrm{n})\end{array}$ & NA & NA & NA & NA \\
\hline & Pooled data & yes & yes & yes & yes \\
\hline & Regulatory & no & no & no & no \\
\hline & Echo core lab & no & no & no & no \\
\hline & $\begin{array}{c}\text { Period of data } \\
\text { collection }\end{array}$ & $1997-2008$ & $1997-2008$ & $1997-2008$ & $1997-2008$ \\
\hline & $\begin{array}{l}\text { Timing of } \\
\text { postop echo }\end{array}$ & 3-6 months & $3-6$ months & 3-6 months & 3-6 months \\
\hline
\end{tabular}

\begin{tabular}{|c|c|c|c|c|c|c|}
\hline \multirow{2}{*}{$\begin{array}{c}\text { Labelled } \\
\text { valve size }\end{array}$} & $\begin{array}{c}\text { Overall } \\
\text { profile } \\
\text { height } \\
{[\mathrm{mm}]}\end{array}$ & $\begin{array}{c}\text { Outflow } \\
\text { profile } \\
\text { height } \\
{[\mathrm{mm}]}\end{array}$ & $\begin{array}{c}\text { Minimum } \\
\text { internal } \\
\text { diameter } \\
{[\mathrm{mm}]}\end{array}$ & $\begin{array}{c}\text { Internal } \\
\text { stent } \\
\text { diameter } \\
{[\mathrm{mm}]}\end{array}$ & $\begin{array}{c}\text { External } \\
\text { stent } \\
\text { diameter } \\
{[\mathrm{mm}]}\end{array}$ & $\begin{array}{c}\text { External } \\
\text { sewing ring } \\
\text { diameter } \\
{[\mathrm{mm}]}\end{array}$ \\
\cline { 2 - 8 } & (A) & (B) & (C) & (D) & (E) & (F) \\
\hline 27 & 18 & 12 & 23.5 & 25 & 27 & 37 \\
\hline $\mathbf{2 9}$ & 19 & 14 & 25.5 & 27 & 29 & 39 \\
\hline 31 & 20 & 15 & 27.5 & 29 & 31 & 41 \\
\hline 33 & 20 & 15 & 29.5 & 31 & 33 & 43 \\
\hline
\end{tabular}

\section{Possible implant positions}

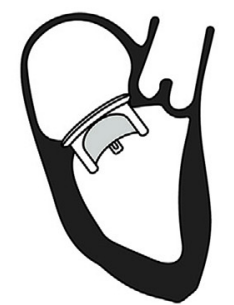

\begin{tabular}{|c|c|c|c|c|}
\hline \multicolumn{5}{|c|}{ Labelled valve size and sizer diameters } \\
\hline Labelled valve size & 27 & 29 & 31 & 33 \\
\hline Diameter, valve related tubular sizer [mm] & 26.2 & 28.4 & 30.5 & 32.1 \\
\hline $\begin{array}{l}\text { DISCLAIMER: Besides tissue annulus diameter, other } \\
\text { debridement, annular positioning, sewing cuff prope } \\
\text { suturing technique and sizing before or after placing } \\
\text { the prosthesis and should be considered during clinic }\end{array}$ & ag. & $t^{\prime \prime}$ & $y$, exte & annula \\
\hline
\end{tabular}

FIGURE 11. Standardized Valve Chart: mitral valves. Information on in vivo hemodynamic performance, physical dimensions, intended implant position and sizer dimensions should be made available for surgical heart valves in the mitral position. EOA, Effective orifice area. 
the aortic position (6) issue date and version number. Valve Charts should have a standardized, uniform layout. Furthermore, to ensure easy access, Valve Charts should be made available online on a designated website endorsed by EACTS, STS and AATS, and in a smartphone application. Valve Charts should be regularly revised and updated if new evidence becomes available. An example of standardized Valve Chart is provided in Figure 10 for aortic valves and in Figure 11 for mitral SHVs.

\section{SELECTION AND COMPARISON OF SURGICAL HEART VALVES USING THE VALVE CHART}

Valve Charts can be used preoperatively, intraoperatively or postoperatively, when comparing different SHVs, when selecting SHVs for implantation or when assessing SHV function. Possible uses of the Valve Charts in various clinical scenarios are summarized in Figure 12.

\section{DISCUSSION}

Easy access to comprehensive information regarding SHV characteristics is required for an optimal SHV choice: in addition to determining which SHV would fit into the patient and knowing the intended annular position of the prosthesis, knowledge of the predicted hemodynamic performance of the SHV and the probability of PPM after implantation are matters of the uttermost importance.

On the standardized Valve Charts, this information could be provided for all SHV models in a uniform manner, without demanding radical changes in current SHV designs or labelling. As most of the required information is readily available, it should be possible to create these Charts relatively quickly and easily. Standardized Valve Charts highlight the necessity of considering multiple factors when selecting an SHV for implantation. The ability to consult such charts during the preoperative, intraoperative and postoperative periods makes objective comparison of different SHVs and optimal SHV selection possible, and it helps in the proper assessment of SHV function during patient follow-up.

Besides the information provided on the Valve Chart, individual patient characteristics, comorbidities, life expectancy and preference, local resources and expertise and

\section{Preoperative comparison of different SHV models.}

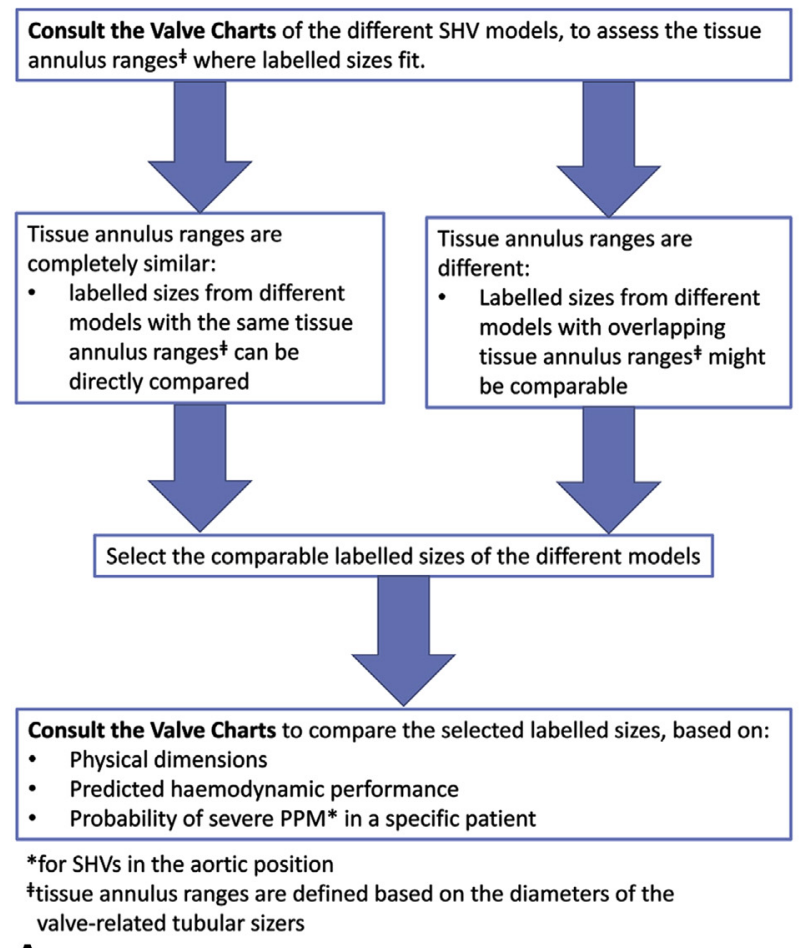

\section{Intraoperative SHV selection, SHV model is already chosen.}

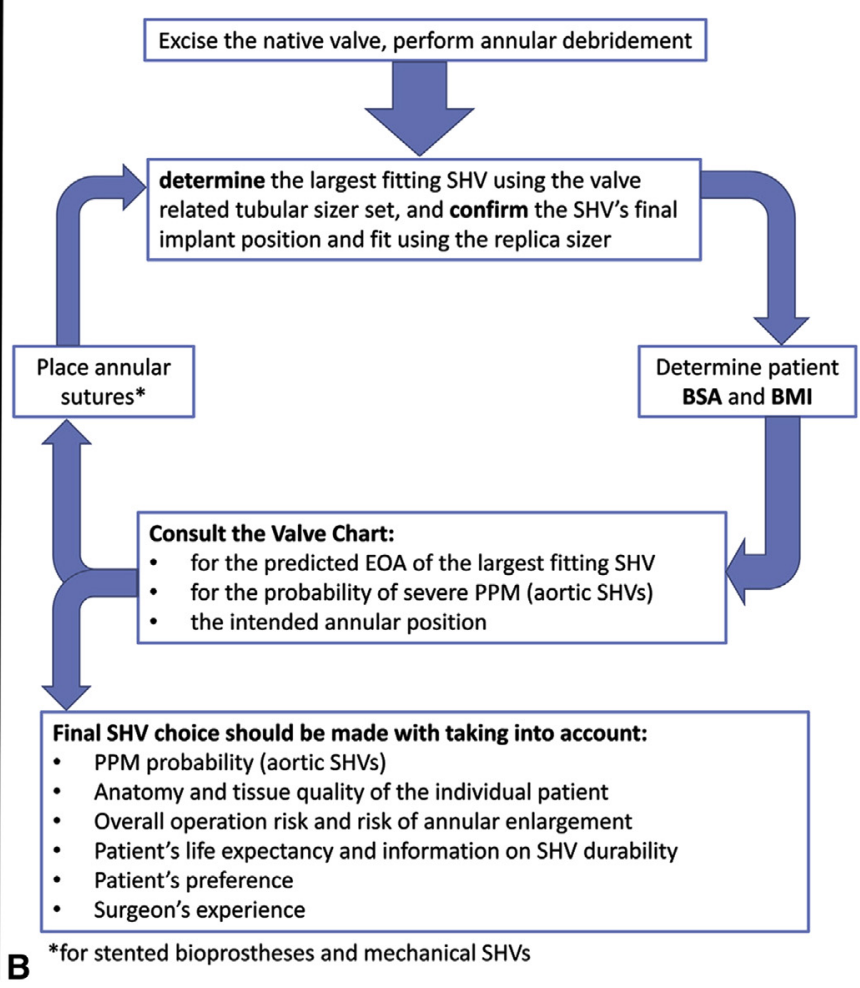

FIGURE 12. Comparison and selection of SHVs using the Valve Chart. Valve Charts can be used in various settings: when comparing SHVs from different manufacturers (A) preoperatively or (B) when selecting SHVs for implantation. SHV, Surgical heart valve; PPM, prosthesis-patient mismatch; BMI, body mass index; $B S A$, body surface area; $E O A$, effective orifice area. 
predicted in vivo prosthesis durability and thrombogenicity should be considered when selecting an SHV for implantation. Due to the suboptimal quality and quantity of the currently available data on in vivo SHV durability and thrombogenicity and considering the significant heterogeneity of the definitions used to describe these important clinical end points, ${ }^{28-30}$ data regarding SHV durability and thrombogenicity are not provided on the Valve Charts.

Problems around SHV sizing and labelling can only be solved by the cooperation and joint effort of all stakeholders. The EACTS-STS-AATS Valve Labelling Project was set up with this intention. This Consensus Document can serve as a guide for regulatory bodies, when developing future standards or when refining the framework of surgical heart valve labelling. In the future, continuous dialogue and close collaboration of clinicians (represented by professional societies), engineers, regulatory bodies, the ISO Cardiac Valves Working Group and valve manufacturers are mandated to ensure that clinicians are provided with the necessary information regarding SHV characteristics all times.

\section{CONCLUSIONS}

This joint EACTS-STS-AATS Valve Labelling Task Force suggests the use of standardized Valve Charts to present essential information on SHV characteristics. Valve Charts should present information on the physical dimensions, implant position and hemodynamic performance of an SHV in a uniform, standardized manner. For valves used in the aortic position, Valve Charts should include a standardized PPM chart to assess the probability of PPM after implantation.

Continuous dialogue and collaboration of clinicians, engineers, regulatory bodies, the ISO Cardiac Valves Working Group and valve manufacturers are essential to ensure that clinicians are provided with the necessary information regarding SHV characteristics.

\section{Conflict of Interest Statement}

Dr Atluri discloses a financial relationship with Abbott, Edwards Lifesciences, and Medtronic; Dr Bapat with Boston Scientific, Edwards Lifesciences, and Medtronic; Drs Chen and Speir with Medtronic; Dr Dahle with Abbott and Tendyne; Dr Elefteriades with CoolSpine, CryoLife, Dura Biotech, Jarvik Heart, Medpace/Vascutek, and Terumo; Dr Tasca with Abbott Medical Italia SpA; Dr De Paulis with CryoLife, Edwards Lifesciences, and Medtronic. All other authors reported no conflicts of interest.

The authors would like to acknowledge the fundamental work of Stuart J. Head in the development of the concept of the standardized PPM charts and the help of Rianne Kalkman in coordinating the Task Force activities. Philippe Pibarot reports grants from Edwards Lifesciences for echocardiography corelab analysis and from Medtronic for in vitro analysis during the conduct of this study. This work was supported by the European Association for Cardio-Thoracic Surgery (EACTS).

\section{References}

1. The European Parliament and the Council of the European Union. Regulation (EU) 2017/745. Available at: http://eur-lex.europa.eu/legal-content/ENG/TXT/ $\mathrm{PDF} /$ ? uri $=$ CELEX:32017R0745\&from $=$ EN. Accessed February 1, 2020.

2. U.S. Food and Drug Administration. Premarket Approval (PMA) FDA. Available at: https://www.fda.gov/medical-devices/premarket-submissions/premarketapproval-pma. Accessed July 2, 2020.

3. ISO. International. Standard, ISO 5840:2015. Cardiovascular Implants-Cardiac Valve Prostheses. International Organization for Standardization (ISO); 2015. Available at: www.iso.org. Accessed February 1, 2020.

4. Durko AP, Head SJ, Pibarot P, Atluri P, Bapat V, Cameron DE, et al. Characteristics of surgical prosthetic heart valves and problems around labelling: a document from the European Association for Cardio-Thoracic Surgery (EACTS) The Society of Thoracic Surgeons (STS)_American Association for Thoracic Surgery (AATS) Valve Labelling Task Force. Ann Thorac Surg. 2019;108: 292-303.

5. Frank M, Ganzoni G, Starck C, Grünenfelder J, Corti R, Gruner C, et al. Lack of accessible data on prosthetic heart valves. Int J Cardiovasc Imaging. 2016;32: 439-47.

6. Bapat VN, Attia R, Thomas M. Effect of valve design on the stent internal diameter of a bioprosthetic valve: a concept of true internal diameter and its implications for the valve-in-valve procedure. JACC Cardiovasc Interv. 2014;7:115-27.

7. Ruzicka DJ, Hettich I, Hutter A, Bleiziffer S, Badiu CC, Bauernschmitt R, et al. The complete supraannular concept: in vivo hemodynamics of bovine and porcine aortic bioprostheses. Circulation. 2009;120:S139-45.

8. Cameron D. Little things matter. J Thorac Cardiovasc Surg. 2015;149:918-9.

9. Christakis GT, Buth KJ, Goldman BS, Fremes SE, Rao V, Cohen G, et al. Inaccurate and misleadingvalve sizing: a proposed standard for valvesize nomenclature. Ann Thorac Surg. 1998;66:1198-203.

10. Walther T, Falk V, Weigl C, Diegeler A, Rauch T, Autschbach R, et al. Discrepancy of sizers for conventional and stentless aortic valve implants. J Heart Valve Dis. 1997;6:145-8.

11. Bartels C, Leyh RG, Matthias Bechtel JF, Joubert-Hubner E, Sievers HH. Discrepancies between sizer and valve dimensions: implications for small aortic root. Ann Thorac Surg. 1998;65:1631-3.

12. Cochran RP, Kunzelman KS. Discrepancies between labeled and actual dimensions of prosthetic valves and sizers. J Card Surg. 1996;11:318-24 [discussion: 25].

13. Ruzicka DJ, Eichinger WB, Hettich IM, Bleiziffer S, Bauernschmitt R, Lange R. Hemodynamic performance of the new St. Jude Medical Epic Supra porcine bioprosthesis in comparison to the Medtronic Mosaic on the basis of patient annulus diameter. J Heart Valve Dis. 2008;17:426-33 [discussion: 34].

14. Lancellotti P, Pibarot P, Chambers J, Edvardsen T, Delgado V, Dulgheru R, et al. Recommendations for the imaging assessment of prosthetic heart valves: a report from the European Association of Cardiovascular Imaging endorsed by the Chinese Society of Echocardiography, the Inter-American Society of Echocardiography and the Brazilian Department of Cardiovascular Imaging. Eur Heart J Cardiovasc Imaging. 2016;17:589-90.

15. Wu C, Saikrishnan N, Chalekian AJ, Fraser R, Ieropoli O, Retta SM, et al. Invitro pulsatile flow testing of prosthetic heart valves: a round-Robin study by the ISO cardiac valves working group. Cardiovasc Eng Technol. 2019;10: 397-422.

16. Retta SM, Kepner J, Marquez S, Herman BA, S Shu MC, Grossman LW. In-vitro pulsatile flow measurement in prosthetic heart valves: an inter-laboratory comparison. J Heart Valve Dis. 2017;26:72-80.

17. Rosenhek R, Binder T, Maurer G, Baumgartner H. Normal values for Doppler echocardiographic assessment of heart valve prostheses. J Am Soc Echocardiogr. 2003; 16:1116-27.

18. Bavaria JE, Desai ND, Cheung A, Petracek MR, Groh MA, Borger MA, et al. The St Jude Medical Trifecta aortic pericardial valve: results from a global, multicenter, prospective clinical study. J Thorac Cardiovasc Surg. 2014;147: 590-7.

19. Sabik JF III, Rao V, Lange R, Kappetein AP, Dagenais F, Labrousse L, et al. Oneyear outcomes associated with a novel stented bovine peri-cardial aortic bioprosthesis. J Thorac Cardiovasc Surg. 2018;156:1368-1377.e5. 
20. Bleiziffer S, Ali A, Hettich IM, Akdere D, Laubender RP, Ruzicka D, et al. Impact of the indexed effective orifice area on mid-term cardiac-related mortality after aortic valve replacement. Heart. 2010;96:865-71.

21. Pibarot P, Dumesnil JG. Hemodynamic and clinical impact of prosthesis-patient mismatch in the aortic valve position and its prevention. J Am Coll Cardiol. 2000; 36:1131-41.

22. Fallon JM, DeSimone JP, Brennan JM, O'Brien S, Thibault DP, DiScipio AW, et al. The incidence and consequence of prosthesis-patient mismatch after surgical aortic valve replacement. Ann Thorac Surg. 2018;106:14-22.

23. Head SJ, Mokhles MM, Osnabrugge RL, Pibarot P, Mack MJ, Takkenberg JJ, et al. The impact of prosthesis-patient mismatch on long-term survival after aortic valve replacement: a systematic review and meta-analysis of 34 observational studies comprising 27186 patients with 133141 patient-years. Eur Heart J. 2012;33:1518-29.

24. Pibarot P, Magne J, Leipsic J, Côté N, Blanke P, Thourani VH, et al. Imaging for predicting and assessing prosthesis-patient mismatch after aortic valve replacement. JACC Cardiovasc Imaging. 2019;12:149-62.

25. Bleiziffer S, Eichinger WB, Hettich I, Guenzinger R, Ruzicka D, Bauernschmitt $\mathrm{R}$, et al. Prediction of valve prosthesis-patient mismatch prior to aortic valve replacement: which is the best method? Heart. 2007;93:615-20.
26. Cohen RG, Bourne ET. Industry-generated charts for the selection of stented aortic valve prostheses: clinical tool or marketing ploy? Ann Thorac Surg. 2011;91:1001-12.

27. Verbraecken J, Van de Heyning P, De Backer W, Van Gaal L. Body surface area in normal-weight, overweight, and obese adults. A comparison study. Metabolism. 2006;55:515-24.

28. Fatima B, Mohananey D, Khan FW, Jobanputra Y, Tummala R, Banerjee K, et al. Durability data for bioprosthetic surgical aortic valve: a systematic review. JAMA Cardiol. 2019;4:71-80.

29. Capodanno D, Petronio AS, Prendergast B, Eltchaninoff H, Vahanian A, Modine $\mathrm{T}$, et al. Standardized definitions of structural deterioration and valve failure in assessing long-term durability of transcatheter and surgical aortic bioprosthetic valves: a consensus statement from the European Association of Percutaneous Cardiovascular Interventions (EAPCI) endorsed by the European Society of Cardiology (ESC) and the European Association for Cardio-Thoracic Surgery (EACTS). Eur J Cardiothorac Surg. 2017;52:408-17.

30. Dvir D, Bourguignon T, Otto CM, Hahn RT, Rosenhek R, Webb JG, et al. Standardized definition of structural valve degeneration for surgical and transcatheter bioprosthetic aortic valves. Circulation. 2018;137:388-99. 


\section{APPENDIX: TASK FORCE MEMBERS \\ Cardiac Surgeons}

Ruggero De Paulis, European Hospital, Rome, ItalyTask Force chairman; Pavan Atluri, University of Pennsylvania, Philadelphia, Pa; Vinayak Bapat, New YorkPresbyterian/Columbia University Medical Center, New York, NY; Duke E. Cameron, Massachusetts General Hospital, Boston, Mass; Filip P.A. Casselman, OLV Clinic, Aalst, Belgium; Edward P. Chen, Emory University School of Medicine, Atlanta, Ga; Gry Dahle, Oslo University Hospital, Oslo, Norway; Andras P. Durko, Erasmus University Medical Center, Rotterdam, The Netherlands; John A. Elefteriades, Yale University School of Medicine, New Haven, Conn; Richard L. Prager, University of Michigan Hospital, Ann Arbor, Mich; Alan Speir, Inova Cardiac and Thoracic Surgery, Falls Church, Va; Giordano Tasca, King Saud Medical City, Riyadh, Kingdom of Saudi Arabia; Thomas Walther, Wolfgang Goethe University, Frankfurt, Germany.

\section{Cardiologists}

Patrizio Lancellotti, University of Liège Hospital, Liège, Belgium; Philippe Pibarot, Laval University, Quebec, QC, Canada; Raphael Rosenhek, Medical University of Vienna, Vienna, Austria.

\section{Engineers}

Jurgen de Hart, LifeTec Group, Eindhoven, The Netherlands; Marco Stijnen, LifeTec Group, Eindhoven, The Netherlands.

\section{ISO}

Ajit Yoganathan, Georgia Institute of Technology/Emory School of Medicine, Atlanta, Ga

\section{US Food and Drug Administration}

Nicole Ibrahim; John Laschinger (until June 2019); Changfu Wu.

\section{Notified Body}

Giovanni Di Rienzo, TÜV SÜD, Munich, Germany (until September 2019).

\section{Competent Authorities}

Alexander McLaren, Medicines and Healthcare products Regulatory Agency, London, UK; Hazel Randall, Medicines and Healthcare products Regulatory Agency, London, UK.

\section{Industry Representatives}

Lisa Becker, Abbott, Chicago, Ill; Scott Capps, CryoLife, Kennesaw, Ga; Brian Duncan, LivaNova, London, UK; Chad Green, Abbott, Chicago, Ill; John C. Hay, Medtronic, Minneapolis, Minn; Stuart J. Head, Medtronic, Minneapolis, Minn; Ornella Ieropoli, LivaNova, London, UK; Ashwini A. Jacob, Edwards Lifesciences, Irvine, Calif; A. Pieter Kappetein, Medtronic, Minneapolis, Minn; Eric Manasse, Abbott, Chicago, Ill; Salvador Marquez, Edwards Lifesciences, Irvine, Calif; William F. Northrup III, CryoLife, Kennesaw, Ga; Tim Ryan, Medtronic, Minneapolis, Minn; Wendel Smith, Edwards Lifesciences, Irvine, Calif. 